\title{
Integrated Urban Micro Farming Strategy Mitigation against Food Crises in Odeda Local Government Area, Ogun State, Nigeria
}

\author{
Abdulsalam-Saghir, P.B. and Oshijo, A. O. \\ Department of Agricultural Extension and Rural Department \\ University of Agriculture, Abeokuta \\ Ogun State, Nigeria \\ E-mail:petrajib@yahoo.com
}

\begin{abstract}
The aim of this study is to evaluate integrated urban micro farming as complementary strategy for mitigating against food crises in Odeda Local Government Area in Ogun State Nigeria by describing the socioeconomic characteristics of the respondents, examine their incidence of food crises, identify factors responsible for food insecurity and identify and describe integrated urban micro farming activities in the study area. Out of about 120 urban and periurban farmers who were involved in urban farming activities eighty (80) respondents were randomly selected Primary data were collected from the respondents with the aid of semi-structured questionnaire and interview- guide. The data were analyzed by means of descriptive statistics such as percentages, frequencies and tables were used to achieve the stated objectives. The result shows that about $62 \%$ engage in integrated farming while majority (41\%) of the respondents' level of income is between $\$ 60,000$ and $\$ 100,000$ and $69 \%$ respondents indicated that their households' size was between 6-10 persons. About $60 \%$ of the respondents experiences food crises. Also about $11 \%$ of the food crises in the study area were as a result of high rate of land lease for city development and $26 \%$ was as a result of inadequate credit facilities while the major (37\%) cause resulted from rapid rural/urban migration. The study concluded that urban micro farming serves as buffer for provision of food to the ever growing teeming population in the cities It was therefore recommended that If micro integrated farming potential is to be exploited to the full, government, the municipalities and the private sector should be involved by making land available both within the city centres and the fringes. There should also be injection of micro loans for urban farmers and favourable policies about urban and peri-urban agriculture should evolve to aid food production.
\end{abstract}

\section{INTRODUCTION}

The contribution of urban agriculture to food security and healthy nutrition is probably its most important asset. Food production in the city is in many cases a response of the urban poor to inadequate, unreliable and irregular access to food, and the lack of purchasing power. In urban settings, lack of income translates more directly into lack of food than in rural settings (cash is needed to buy food). The cost of supplying and distributing food from rural areas, or importing food for cities, is rising continuously, and its distribution within the cities is uneven. As a 


\section{Journal of Agricultural Extension}

Vol. 13 (1) June, 2009

consequence, urban food insecurity will continue to increase at an increasing rate (Argenti, 2000).

Food is a basic necessity of life. Its importance is seen in the fact that it is a basic means of sustenance and adequate food intake, in terms of quality and quantity, is a key for healthy and productive life. The importance of food is also shown in the fact that it accounts for a substantial part of a typical Nigerian household budget and these serves as important "vehicles" for taking nutrients into the body and bringing about human pleasure, hence, the need for food to be taken in the right quantity and quality. The economic development of a nation is dependent on the productive capacity of the human resources and the productive capacity of the human resources is however a function of how well fed they are which has multiplier effect on their general wellbeing. According to Okunmadewa, (2001), the concern for food security and nutritional well being in an economy is predicted by role of human element in economic development. Food crises, with regards to quality and quantity are one of the plagues of a developing country like Nigeria.

The number of people around the world who live in and around cities is increasing steadily. The "State of the World Cities" by United Nations Human Settlements Programme (UN-Habitat) (2001) predicts that by year 2030, 60 percent of the world's population will live in cities. The growth of cities is due to the natural growth of urban population and migration from rural areas to cities, with the former gradually becoming more important than the latter (Drescher, 1997). There is general consensus that urban population will continue to grow rapidly in most developing countries in the decades to come. Rapid urbanization leads to a continuous extension of the city into the rural suburbia, bringing large areas under the direct influence of the urban centres. This peri-urban interface according to Brook and Davila, (2000) is characterized by rapid land use changes and changing livelihoods.

Until recently poverty was synonymous with rural conditions, but the rapid urbanization of many developing countries has given birth to a large class of urban poor. The worldwide urban population is expected to double in 30 years, but the numbers of urban poor are expected to increase at a greater rate. Estimates based on health and environmental conditions suggest about 600 million people in cities live in unhealthy conditions. Hence, as Africa and parts of Asia will become increasingly urban over the next 25 years, urban poverty and food insecurity could worsen if preventive measures are not taken. (FAO, 1996).

The increase in urban poverty is accompanying the urbanization process and poverty is concentrating gradually in the urban areas (Abdulsalam-Saghir, 2008). This indicates that cities are quickly becoming the principal territories for intervention and planning of strategies that aim to eradicate hunger and poverty and improve livelihoods, requiring innovative ways to stimulate local economic development in combination with enhancing food security and nutrition.

There are currently about 350 million persons in the developing nations who do not get enough to eat. They also suffer from poor access to water, building materials, and fuels. The percentage of the population that is sick and undernourished, mainly children, is increasing in urban areas much faster than in rural areas. In 15 years, more than 50 per cent of residents in these countries will live in cities. At present, 37 countries throughout every region of the world are experiencing localized food insecurity, lack of access to food, or shortfalls in food production or supplies. In the past year, global food prices have increased to an average of 43 percent and World Bank estimated that the doubling of food prices during the past three years could potentially push 100 million people throughout the world into extreme poverty (FAO, 1995; FAO, 1996). 
The traditional local agricultural and land distribution system is disrupted by urban newcomers seeking to buy land (for speculation, for mining of loam, sand and stones, for infrastructure development, for construction, for more urbanized types of agriculture) leading to an increase of land prices. In response, some of the traditional farmers are giving up farming, selling their land and switching to other income earning activities; in other households the males (mainly) are engaging in urban jobs while the females take main responsibility for the farming operations (Abdulsalam-Saghir, 2008).Yet, another part of the (now) peri-urban farmers are starting to intensify their farming systems and to adapt to the new more urban conditions( change of crops, market orientation, use of new technologies such as production under covers, direct marketing, use of urban organic wastes or wastewater. The interdependence between urban and surrounding rural areas creates the need for integrated development approaches (Purushothaman and Robert, 2004), which calls for rethinking domains of interest, institutional change and innovative planning approaches.

\section{Objectives of the study}

In view of these, the main purposes of this study are to:

(i) describe the socioeconomic characteristics of the respondents in the study area in relation to the present food crisis in Nigeria;

(ii) examine the incidence of food crises in the study area;

(iii) identify factors responsible for food insecurity in the study area;

(iv) identify and describe integrated urban micro farming activities in the study area.

\section{METHODOLOGY}

This study was carried out in the Odeda Local Government area of Ogun State which is located in the North Western region of Ogun State with a land area of about 1, $26545 \mathrm{sq} \mathrm{km}$ and a population of about 21,7000 people who largely speak the Egba dialect of the Yoruba language. The area spans Northward of Abeokuta South Local Government area from Obantoko to Bakatari and Eleso near Ibadan, Oyo State. It is bounded in the east by Obafemi-Owode Local Government area of Ogun State and in the West by Ibarapa Local Government area of Oyo State. Apart from these; Odeda Local Government area also shares boundary with Egbado North Local Government of Ogun State to the North West. (NPC, 2006)

This study covered the urban and peri-urban farmers in the circles of the selected blocks of the extension zone in Odeda Local Government area. These are llugun, Odeda, Olodo, Osiele, Ikereku, Opeji, Alabata, Sanusi, Araromi, ljo Agbe. Out of 120 urban and peri-urban farmers who are involved in urban farming activities such as Aquaculture, Bee keeping, Poultry, Piggery, and Livestock rearing and crop production in the selected areas, eighty (80) respondents were randomly selected from the list gotten from Association of Urban Farmers in the study area. Primary data on respondents' socioeconomic characteristics, incidence of food crises, factors responsible for food crises and identification of integrated micro farming at both nominal and ratio levels were collected from the respondents with the aid of semi-structured questionnaire and interview- guide. The data were analyzed by means of descriptive statistics such as percentages, frequencies and tables were used to achieve the stated objectives. 
Journal of Agricultural Extension

Vol. 13 (1) June, 2009

\section{RESULTS AND DISCUSSION}

\section{Socio- economic characteristics of urban farmers in the study area}

The result reveals that $19 \%$ of the respondents were less than 20 years, $29 \%$ were in the age range of $20-30$ years and in their active age for integrated farming, $20 \%$ were in the age range $30-40,20 \%$ were in the range of $40-50$ years, $16 \%$ were in the range of 50 years and above. Findings from the study revealed that $70 \%$ of the respondents were male while $30 \%$ were female. Also $76 \%$ of the respondents were married with only $13 \%$ single while $11 \%$ of the respondents were divorced. A larger proportion of the respondents (33\%) had only secondary school education, $29 \%$ of the respondents had no formal education. Only $26.3 \%$ had tertiary school education. Also, $63 \%$ engage in integrated farming while majority $(41 \%)$ of the respondents' level of income is between N60,000 and N100,000 while $68.8 \%$ respondents indicated that their household size was between 6-10 persons. It could be deduced from the finding that engagement in farming activities in the city is a coping strategy by which respondents with large household size escape from food crises in their households. This is in line with the report of Baumgartner et. al (2000) that the main driving forces for farmers to become engaged in urban agriculture are for food security and income generation. This also corroborated with Smith et.al. (1996) and Mougeot (1998) opined that in most developing countries, the urban farmers belong to low-income groups. Armar-Klemesus and Margaret( 2000) also reported that urban agriculture is practiced mostly among the urban poor as part of a coping strategy. The findings of Kiguli (2005), also agrees with this finding that urban agriculture is practiced in informal settlement where low-income earners can be found. The survey revealed that $62.5 \%$ of the respondents generate all their income from agricultural related activities while $37.6 \%$ of the respondents have other means of generating additional income. The implication of the finding is that majority of the respondents rely solely on integrated farming as a coping strategy against food crises. Farming therefore is a major means of escaping poverty and hunger for these households. 
TABLE 1: Distribution of Respondents by their Socio-Economic characteristics

\begin{tabular}{|c|c|c|}
\hline Parameters & Frequency & Percent \\
\hline \multicolumn{3}{|l|}{ Age (years) } \\
\hline $10-20$ & 15 & 18.8 \\
\hline $20-30$ & 23 & 28.8 \\
\hline $30-40$ & 16 & 20.0 \\
\hline $40-50$ & 13 & 16.3 \\
\hline Above 50 & 13 & 16.3 \\
\hline \multicolumn{3}{|l|}{ Sex } \\
\hline Male & 56 & 70.0 \\
\hline Female & 24 & 30.0 \\
\hline \multicolumn{3}{|l|}{ Religion } \\
\hline Christianity & 38 & 38.8 \\
\hline Islam & 31 & 47.5 \\
\hline Traditional believe & 11 & 13.8 \\
\hline \multicolumn{3}{|l|}{ Marital status } \\
\hline Single & 10 & 12.5 \\
\hline Married & 61 & 76.3 \\
\hline Divorced & 9 & 11.3 \\
\hline \multicolumn{3}{|l|}{ Educational status } \\
\hline No formal education & 23 & 28.8 \\
\hline Primary & 10 & 12.5 \\
\hline Secondary & 26 & 32.5 \\
\hline Tertiary & 21 & 26.3 \\
\hline \multicolumn{3}{|l|}{ Household size } \\
\hline $1-5$ & 19 & 23.8 \\
\hline $6-10$ & 55 & 68.8 \\
\hline $11-15$ & 6 & 7.5 \\
\hline \multicolumn{3}{|l|}{ Source of income } \\
\hline Farming & 50 & 62.5 \\
\hline Civil services & 3 & 3.8 \\
\hline Artisan & 26 & 32.5 \\
\hline Trading & 1 & 1.3 \\
\hline \multicolumn{3}{|l|}{ Level of income $(\mathrm{N})$} \\
\hline Below 60,000 & 8 & 10.0 \\
\hline $61,000-75,000$ & 33 & 41.3 \\
\hline $76,000-85,000$ & 17 & 21.3 \\
\hline $86,000-95,000$ & 16 & 20.0 \\
\hline Above 100,000 & 6 & 7.5 \\
\hline
\end{tabular}

Source: Field Survey, 2008 
Journal of Agricultural Extension

Vol. 13 (1) June, 2009

\section{Food Security Status of Respondents}

As shown on table 2, $40 \%$ of respondents were food secured with their food security index score of $1.30,38 \%$ had 1.03 index and this signified low risk and $15 \%$ were food secured with medium risk of 0.95 score while $7 \%$ respondents were food insecure with severe hunger and their index were 0.47 indicating extreme risk. Further probing into the proportion of respondents' income that is spent on household food consumption also supported these finding because $61.3 \%$ of the respondents spent between $25 \%$ to $75 \%$ of their income on household food consumption despite their high involvement in integrated farming. This implies that huge amount of respondents' income is spent on household consumption and they might not enable them to invest in other equally important investments.

TABLE 2: Distribution of Respondents based on their Food Security Status

\begin{tabular}{lccc}
\hline \multicolumn{1}{c}{ Parameters } & Frequency & Percentage & Score \\
\hline Proportion of income spent on food & & & \\
Below 25\% & 18 & 22.5 & - \\
$25-50 \%$ & 9 & 11.3 & - \\
$51-75 \%$ & 31 & 27.5 & - \\
More than 75\% & & 38.8 & \\
Food security risk status & 32 & 40.0 & 1.30 \\
Food secure (none) & 30 & 37.5 & 1.03 \\
Food insecure without hunger (low) & 12 & 15.0 & 0.95 \\
Food insecure with hunger (medium) & 6 & 7.5 & 0.47 \\
Feed insecure with hunger (extreme) & & & \\
\hline
\end{tabular}

Source: Field Survey, 2008

\section{FACTORS RESPONSIBLE FOR FOOD CRISES OF THE RESPONDENTS}

As shown on Table 2, several factors that has contributed to food crises in the study area are that about $3.75 \%$ of the food crises in the study area was as a result of over population and demand for more buildings, $6.3 \%$ were caused by shortage in food production, $11.3 \%$ were caused by drudgery in agriculture, $2.5 \%$ were caused by inadequate/lack of marketing channels for the various agricultural produce of the farmers, $2.5 \%$ were caused by inadequate labor. Also about $11.25 \%$ of the food crises in the study area was as a result of high rate of land lease for city development and $25.5 \%$ was as a result of inadequate credit facilities while the major $(37.5 \%)$ cause resulted from rapid rural/urban migration of the active age group in to the city for 'white collar' job and thereby causing rural-urban food crises. 
TABLE 3: Distribution of respondents based on factors that are responsible for food crises

\begin{tabular}{lll}
\hline Causes of food Crises & Frequency & Percentage \\
\hline Over population & 3 & 3.75 \\
Shortage of food production & 5 & 6.30 \\
Drudgery in Agriculture & 9 & 11.3 \\
Lack of marketing channel & 2 & 2.50 \\
Inadequate labour & 2 & 2.50 \\
High rate of land lease & 9 & 11.25 \\
Rural /Urban migration & 30 & 37.5 \\
Inadequate credit facilities & 20 & 25.0 \\
\hline
\end{tabular}

Source: Field Survey, 2008

\section{IDENTIFY AND DESCRIBE INTEGRATED URBAN MICRO FARMING ACTIVITIES}

As shown on Table $4,37.5 \%$ of the respondents were full time farmers while $62.5 \%$ of them were part time farmers. The study revealed that $58.85 \%$ of the respondents practiced integrated micro farming, $32.5 \%$ practiced crop farming while $8.8 \%$ are into livestock production. The level of involvement in agriculture is determined by the various agricultural activities in which people are engaged. This goes in line with Mougeot (2000) reported that 800 million people worldwide engaged in urban agriculture out of which 150 million people are full time farmers. The farm sizes of the respondents were measured in plots to reflect the urban nature of the study. It was revealed that $36.3 \%$ of the respondents had farm sizes that were more than three plots (a plot is $60 \mathrm{ft}$ by $120 \mathrm{ft}$ ), $23.8 \%$ have less than three plots, $35 \%$ have less than two plots while $5 \%$ have less than one plot, and this implies that little or no mechanised farming is possible or practiced in the study area. This could be one of the reasons for the food crises.

The finding also indicates that integrated urban micro farming is playing a major role in enhancing household food security and also serves as a means by which people escape from hunger and poverty. As shown on the table, $43.8 \%$ of the respondents had high level of involvement, $26.3 \%$ had medium level of involvement while $30 \%$ had low level of involvement. The distribution of the respondents by types of integrated farm practiced showed that $38 \%$ were involved with combining animal rearing and crop farming on their available plots of land while $23 \%$ combined animal rearing, crop and poultry on their available plots of land. This implies that lands are not readily available for mono cropping and expansion. 
Journal of Agricultural Extension

Vol. 13 (1) June, 2009

TABLE 4: Distribution of Respondents based on various Integrated Farm Practiced

\begin{tabular}{lll}
\hline Farming status & Frequency & Percentage \\
\hline Seasonal & 12 & 15.0 \\
Periodic & 16 & 20.0 \\
Temporal & 22 & 27.5 \\
Full-time & 30 & 37.5 \\
Type of farming Practiced & & \\
Crop farming & 26 & 32.5 \\
Livestock Farming & 7 & 8.80 \\
Integrated farming & 47 & 58.8 \\
Level of involvement in & &
\end{tabular}

Agricultural activities

High level of involvement

Medium level of involvement

21

26.3

Low level of involvement

24

30.0

Types of integrated farm practiced

Fish pond + Poultry 3

3.9

Poultry + Crops+ animal rearing

18

22.5

Crop + fish pond

8

12.5

Animal rearing + crop

30

37.5

Poultry + crop

19

23.8

Farm Size for integration

Less than one plot 4

5.0

Less than two plots

Less than three plots

19

23.8

More than three plots

29

36.3

Source: Field Survey, 2008 


\section{RECOMMENDATION}

This study has demonstrated that integrated urban micro farming as practiced in Odeda Local Government Area of Ogun State can be viable if several logistics are put in place. The visible growth in urban and peri-urban agriculture throughout the world casts a spotlight upon some existing issues in agriculture and food security.

- Policy makers in the city should make more land available both within the city centres and the fringes. This will encourage more people to go into urban farming thereby increasing food access in the cities.

- The major constraint currently faced by the urban farming practitioners is lack of credit. Therefore, government should further make it mandatory for all the financial institutions in the country to dedicate a certain proportion of their loan facilities to agriculture. This will encourage more skilful people to go into farming rather than looking for non-existing 'white collar' jobs.

- More enlightenment campaigns are required to educate people on the need to reduce their household sizes by adhering to family planning. This will reduce the burden of spending a larger proportion of their income on household food consumption thereby enhancing their standard of living.

\section{REFERENCES}

Abdulsalam-Saghir, P.B. (2008): "Women Empowerment and Natural Resource Use: A Model for Choice Consideration in Poverty Reduction Policy". Journal of Sustainable Development. Vol. 5. No.1/2 pp12-18.

Argenti, Olivio, (2000): "Food for the Cities: Food Supply and Distribution Policies to reduce Urban Food Insecurity". FAO, Rome.

Armar-Klemesus, Margaret, A. (2000): "Urban Agriculture and Food Security, Nutrition and health. In: Bakker, N., M. Dubbeling, S.Guedel, U. Sabel Koschella, H. de Zeeuw (eds). 2000. Growing Cities, Growing Food, Urban Agriculture on the Policy Agenda. DSE, feldafing Germany, 99-118.

Baumgartner, B. and Belevi, H (2001): "Systematic Overview of Urban Agriculture in Developing Countries". EAWAG-Swiss Federal Institute for Environmental Science and Technology SANDEC. Dept of Water \& Sanitation in Developing Countries. Pp 5-15.

Brook and Davila,(2000): “The Peri-Urban Interface, A Tale of Two Cities'. School of Agricultural and Forest Sciences, University of Wales and Development Planning Unit, University College London.

Drescher, A.W. (1997): "Urban Agriculture in Seasonal Tropics of Central, Southern Africa", A Paper presented at the International Conference on Sustainable Urban Systems, May, 22-25, Ryerson, Polytechnic, Toronto, Canada.

FAO (1996): "Towards Universal Food Security: Draft of a Policy Statement and Plan of Action" WFS 96/3. FAO Rome, March.

FAO. (1995): "Urban and Peri-urban Agriculture", UNFAO/ Committee on Agriculture (COAG/COAG15/x0076). 


\section{Journal of Agricultural Extension}

Vol. 13 (1) June, 2009

Kiguli, J. (2005)." Contribution of urban agriculture to food security in Uganda". Paper presented at the African Local Government Action Forum (ALGAF), phase V: session VI.

Mougeot L.(2005): Agropolis: The social, political and environmental dimensions of urban agriculture. Earthsan. London-UK.

National Population Census Record 2006

Okunmadewa, F. (2001) :Poverty Reduction in Nigeria: A Four-Point Agenda. Annual Guest Lecture of the House, University of Ibadan.

Purushothaman, Sangeetha, Robert Brook and Simone Purohit, (2004): "Transcending ruralurban boundaries: In Habitat Debate (forum): Cities, Engines of Rural Development, September 2004. Vol. 10. No.3.

Smith, Jack., Annu Ratta, and Joe Nasr, (1996): “ Urban Agriculture: Food, Jobs and Sustainable Cities”. UNDP, Publications Series For Habitat II. Vol. 1. UNDP, New York.

United Nations Centre for Human Settlements (UN-HABITAT), (2001): "Tools to Support Participatory Urban Decision Making". Nairobi Kenya. 